\title{
EFFECT OF PLANT VARIETIES AND POTASSIUM FERTILIZATION ON THE POPULATION DENSITIES OF CERTAIN HOMOPTEROUS INSECTS INFESTING CUCUMBER AND SQUASH PLANT VARIETIES
}

Hegab, Ola I. M. and A. M. S. Hegab

Plant Prot. Dept., Fac. Of Agric., Zagazig Univ. Zagazig, Egypt

\begin{abstract}
The present investigation aimed to study the effects of some cucumber varieties:- Indian, Japanese and Alpha beta, while squash varieties Holland, Escandarani and Top Kapi on the population density of aphids, leafhoppers and whitefly insects, under different potassium fertilization levels(zero,50,100 and $200 \mathrm{~kg} / \mathrm{feddan}$ ). The obtained results show pronounced differences in the population density of the aforementioned insects on the tested varieties. The least susceptible variety of cucumber was Indian, while the highest susceptible variety was Alpha beta, The least susceptible squash was Holland variety, while the highest susceptible was Top Kapi variety during 2006 and 2007 seasons, respectively .The fourth level of potassium fertilization "200kg.potassium sulphate /feddan" recorded the least number of aphids, leafhoppers and whitefly insects, while the first level of potassium fertilization "zero kg.potassium sulphate/feddan" increased the aforementioned insects population density .

Chemical analysis results showed a negatively relationship between protein, carbohydrate contents and $\mathrm{pH}$ values and aphids, leafhoppers and whitefly infestation in all cucumber and squash varieties.

From these results susceptibility of plant variety and potassium fertilization must be considered in the integrated pest management programs as they play very important role in depressing insect population.
\end{abstract}

\section{INTRODUCTION}

Homopterous insects (leafhoppers, aphids and whitefly insects) are great economic pests of Cucurbitaceous vegetable plants which cause serious damage directly by sucking plants juice and indirect damage by phytopathogenic viruses transmission (Hegab et al 1989b;Hector et al ,2008 and Hunter and Gray ,2008). Aforementioned insects infestation also reduce cucumber and squash yields. Host plant varieties exhibited different susceptibility to the aforementioned homopterous insects infestation. So the resistant varieties could be used as an item in integrated pest management programs .On the other hand fertilization had an important role on those insects infestation (Hegab, Ola, 2001 and Hashem,2005).

So the present investigation aimed to survey the aphids, leafhoppers and whitefly insects on cucurbitaceous vegetable plants (cucumber and squash ) and also to study the seasonal abundance of the dominant insect species as well as to estimate the effects of plant varieties ,potassium fertilization and their chemical constituents on the population density of the aforementioned homopterous insects during 2006 and 2007 seasons . 


\section{MATERIALS AND METHODS}

1) Survey and seasonal abundance of certain homopterous insects infesting cucumber and squash plants.

An area about $3000 \mathrm{~m}^{2}$ was chosen to carry out this study in DiarbNigm district ,Sharkia Governorate , the experimental design used in all growing seasons of cucumber and squash plants during summer plantation throughout 2006 and 2007 seasons was a split plot design with three replications. Treatments were distributed as plot within replication ,each sub plot consisted ( 5 meters wide and 7.5 meters length). The seedling date of cucumber and squash plants was the first week of May. The normal agricultural practices were followed in due time and all plots were kept free of any insecticides treatments.

Sampling started when the age of the plants reached about 21-28 days after seedling and continued at weekly intervals throughout the growing seasons. The following two procedures of sampling were used:

I) Plant samples, three leaves representing different strata, viz. terminal, middle and bottom parts were taken randomly from 10 plants of each variety. These leaves were examined in the laboratory using a binocular microscope and the total number of existing nymphs, aptera, and alate forms of aphids, immature and adult stages of whitefly insects were recorded on both surfaces of the leaves.

II) Sweeping net, $30 \mathrm{~cm}$ diameter and $60 \mathrm{~cm}$ depth. Each sample consisted of 100 double strokes were taken from both diagonal directions of the experimental area. Each sample was kept in a tight closed paper bag and transferred to the laboratory for inspection by binocular microscope and the collected leafhoppers were killed by cyanide, sorted into species and identified according to the work of Nielson (1968) and Hegab et al. (1989a). Counts of captured leafhoppers were done and recorded for each sample.

Daily records of both maximum and minimum temperatures along with relative humidity were obtained from the Agrometeorological Station at Zagazig city which is located closely to the experimental areas during 2006 and 2007 seasons.

2) Effects of some agricultural practices on the population density of certain homopterous insects infesting cucumber and squash plants I) Plant varieties

For this purpose three cucumbers plants (Cucumis sativus)varieties, namely Indian,Japanese and Alpha beta were used, while squash plants (Cuucurbita pepo var. melopepo L) varieties were Holland, Escandarani and Top Kapi .

\section{II) Potassium fertilization levels}

Four potassium fertilization levels $(00.50,100$ and $200 \mathrm{~kg} / \mathrm{feddan}$ were applied in these experiments as potassium sulphate $48 \% \mathrm{~K}_{2} \mathrm{O}$, half of the quantity during preparing the soil and the rest quantity after 30 days from seedling. 
The relationships between different plant varieties, potassium fertilization levels and the population density of the aforementioned insects were statistically analyzed according to split design Little and Hills, (1975).

3) Relationship between certain chemical constituents of cucumber and squash plant varieties and infestation with aphids, leafhoppers and whitefly insects

To confirm the relationship between certain chemical constituents of the different varieties of host plants and the infestation with aphids ,leafhoppers and whitefly insects, chemical analysis of the cucumber and squash varieties leaves were carried out in central laboratory ,Faculty of Agriculture ,Moshtohour ,Banha Univ. to determine the total protein ,carbohydrate ,phosphorous, calcium ,potassium contents and $\mathrm{pH}$ value ,according to Dubois et al., 1956; Barrowes and Simpson,1962 and Bremmer and Mulvaney, 1982.

Each sample from a field plot consists of 30 leaves free of insects or disease. Collected samples taken prior to the fruiting stage .

Effects of different potassium fertilization rates and the chemical constituents of different varieties on the population density of the aforementioned homopterous insects were statistically analyzed according to split design (Little and Hills, 1975).

\section{RESULTS AND DISCUSSION}

\subsection{Survey of some homopterous insects on cucumber and squash plants.}

\section{a) Aphid insects}

Survey studies on cucumber and squash plants in Diarb-Nigm district, Sharkia Governorate showed the occurrence of the following aphid species:- Aphis gossypii (Glover) and Myzus persicae (Sulz.)

As shown in Table (1) Myzus persicae (Sulz.) proved to be the most dominant aphid species on cucumber and squash plants followed by Aphis gossypii (Glover) during 2006 and 2007 seasons.

b) Leafhopper insects

The data presented in Table (1) show the incidence of eight leafhopper species belonging to family Cicadellidae on cucumber and squash plants at Diarb - Nigm district ,Sharkia Governorate during 2006 and 2007seasons.

The collected leafhopper species were arranged descendingly according to their abundance as follows, Empoasca decedens(Paoli), E. decipiens (Paoli), Cicadulina china (Ghauri) , Balclutha hortensis (Lindb.), Nephotettix apicalis (Matsch),Circulifera tenellus(Baker), E. distinguend (Paoli) and E lybica (de Berg)

$E$. decedens , E. decipiens and C. chinai were the most abundant leafhoppers species on cucumber and squash plants during the whole period of study. While the rest leafhopper species were found in low number. 
Hegab, Ola I. M. and A. M. S. Hegab

1

2136 
In both seasons, it seems that the number of all species collected from cucumber plants were higher than those collected from squash plants. These results are in agreement with those of Hegab et al. (1989b) who recorded the aforementioned species on cucurbitaceous vegetable plants in Salhia district,Sharkia Governorate.

\section{c) Whitefly insects}

The total number of whitefly Bemisia tabaci (Genn.) individuals infesting cucumber and squash plants during 2006 and 2007 seasons are shown in Table ( 1 ).

In both seasons, it seems that the total number of $B$. tabaci collected from cucumber were higher than those collected from squash plants. Also the total number of collected whitefly insects during 2007 season was higher than those recorded in 2006 season.

\subsection{Seasonal abundance of the dominant homopterous insects a) Aphid insects i) Myzus persicae}

Tables (2-5) showed that the population density of $M$. persicae recorded one peak on cucumber and squash plants at the $4^{\text {th }}$ week of August $(137,195$ insects/sample on cucumber and 240,317 insects/sample) on squash at $30.4 \mathrm{C}^{\circ}, 31.2 \mathrm{C}^{\circ}$ with $65.4 \%$ and $65.5 \%$ \%R.H. in 2006 and 2007season ,respectively .

\section{ii)Aphis gossypii}

One peak of $A$. gossypii population density occurred on cucumber plants and squash plants, it was observed in the $4^{\text {th }}$ week of August $(112,288$ insects/sample on cucumber plants and 190,270 insects/sample on squash plants) at $30.4 \mathrm{C}^{\circ}, 31.2 \mathrm{C}^{\circ}$ with $65.4 \%$ and $65.5 \%$ R.H. in 2006 and 2007seasons, respectively .

This result agree with Berlandir, et al,1997, Berry,1998,Kozma et al,2001 and Webb 2007 who recorded that the melon aphid, Aphis gossypii, and the green peach aphid, Myzus persicae, are common on squash and cucumber plants.

\section{b) Leafhopper insects}

Empoasca decedens, E. decipiens and Cicadulina chinai were the most abundant leafhopper species on cucumber and squash plants during 2006 and 2007 seasons .

\section{i) Empoasca decedens and E. decipiens}

The weekly numbers of $E$. decedens and $E$. decipiens collected from cucumber and squash plants in 2006 and 2007seasons are recorded in Tables (2-5) .One peak of the aforementioned species population density were recorded on both cucumber and squash plants. It occurred at $4^{\text {th }}$ week of August with a total number of 27,43 insects/sample for $E$. decedens and26,38 insects/sample for $E$. decipiens on cucumber plants ,while on squash plants it was 49,56 insects/sample for $E$. decedens and 38,47 insects /sample for $E$. decipiens at a mean temperature of $30.4 \mathrm{C}^{\circ}, 31.2 \mathrm{C}^{\circ}$ with $65.4 \%$ and $65.5 \%$ R.H. in 2006 and 2007 seasons , respectively. 
Hegab, Ola I. M. and A. M. S. Hegab

2 
J. Agric. Sci. Mansoura Univ., 34 (3), March, 2009

3

2139 
Hegab, Ola I. M. and A. M. S. Hegab

4

2140 
J. Agric. Sci. Mansoura Univ., 34 (3), March, 2009

5

2141 


\section{ii) Cicadulina china $i$}

The population density of $C$. chinai showed one peak of abundance during the summer plantation of cucumber and squash Tables(2-5), The peak occurred in $4^{\text {th }}$ week of August with a mean number of 21,35 insects/sample on cucumber plants and 37,52 insects/sample on squash plants at $30.4 \mathrm{C}^{\circ}$, $31.2 \mathrm{C}^{\circ}$ with $65.4 \%$ and $65.5 \%$ R.H. in 2006 and 2007 seasons ,respectively .This result agree with Hashem,2005 who recorded that $E$. decedens and $E$. decipiens are the most leafhopper species abundant on squash plantations.

\section{c) Whitefly insects Bemisia tabaci}

The total number of $B$. tabaci specimens collected from cucumber and squash plants during 2006 and 2007 seasons are shown in Tables (2-5)

The obtained results show that the number of B.tabaci individuals fluctuated with general tendency to increase throughout the successive samples until reaching the peak of population density .Careful view of Tables (2-5) indicated that one peak representing high population density of whitefly individuals on cucumber and squash plants was recorded during the $1^{\text {st }}$ week of September with a total number of 441,548 insects/sample on cucumber plants and 297,358 insects/sample on squash plants at $28.0 \mathrm{C}^{\circ}, 32.3 \mathrm{C}^{\circ}$ with $62.5 \%$ and $67.1 \% \mathrm{RH}$. for the two seasons, respectively. This results agree with those of Raupach et al, 2002 and Hector et al., 2008 who recorded that whitefly insects are the principal insect pests in greenhouse production of cucumbers in Florida and it can build up to high numbers in cucumber and squash.

\subsection{Effects of some agricultural practices on the population density of certain homopterous insects infesting cucumber and squash plants 3.3.1 Plant varieties}

The influence of different plant varieties on the occurrence of aphids, leafhoppers and whitefly insects attacking cucumber and squash plants under field conditions at Diarb-Nigm district, Sharkia Governorate were studied during 2006 and 2007seasons and the results are shown in Tables (6-7).

\section{l) Cucumber plants}

\section{a) Aphid insects}

Results given in Tables (6 and 7) indicated that the tested three cucumber varieties could be arranged in descending order to the population density of aphid insects as follows : Alpha beta variety infested with a mean number of 65.125and 114.075 insects/sample for A.gossypii , 79.825and 103.875 insects /sample for $M$. persicae ,Japanese (50.95 and 89.05 insects/sample for A.gossypii, 67.125 and 83.775 insects /sample for $M$. persicae and Indian variety ( 42.025 and 69.1 insects/sample for A.gossypii , 47.475and 69.575 insects /sample for M. persicae )in 2006 and 2007 seasons, respectively .

\section{b) Leafhopper insects}

As shown in Tables (6 and 7) it could be noticed that the most susceptible variety was Alpha beta variety (19.975 and 24.475 insects/sample for $E$. decedens,16.75and 23.025 insects /sample for $E$. decipiens and 11.70 and 21.025 insects/sample for $C$. china), followed by Japanese variety (15.725 and 20.925 insects/sample for $E$. decedens 
,13.625and 18.45 insects /sample for E. decedens and 10.05 and 16.2 insects/sample for C. china during 2006 and 2007 seasons, respectively), whereas the lowest population density was recorded on Indian variety (11.65 and 17.2 insects/sample for E.decedens,8.675 and 13.8 insects /sample for E. decipiens and 8.1 and 12.05 insects/sample for C.china )in both seasons ,respectively .

c) Whitefly insects

As obvious in Tables (6 and 7) the lowest mean number of whitefly insects $B$. tabaci was recorded on Indian variety infested with a mean number of 187.775 and 229.05 insects/sample, followed by Japanese variety (233.125 and 272.025 insects/sample), whereas the highest population density was observed on Alpha beta variety infested by 279.4 and 334.475insects/sample for 2006 and 2007 seasons, respectively.

Generally, from the obtained results, it could be concluded that Alpha beta variety was more susceptible to aphids, leafhoppers and whitefly insects infestation, whereas Indian variety was the least susceptible variety.

\section{II)Squash plants}

\section{a) Aphid insects}

Results given in Tables (6 and 7) indicated that the population density of aphid insects on the tested three squash varieties could be arranged in descending order as follows : Top Kapi variety infested with a mean number of 137.825 and 185.15 insects/sample for $A$. gossypii , 157.475 and 189.275 insects /sample for M. persicae for 2006 and 2007 seasons, respectively, Escandarani variety (103.4 and 150.625 insects/sample for $A$. gossypii, 142.4 and 176.175 insects /sample for M. persicae and Holland variety (90.775and 118.25 insects/sample for $A$. gossypii , 118.325 and 147.65 insects /sample for M. persicae during 2006 and 2007 seasons ,respectively.

\section{b) Leafhopper insects}

As shown in Tables (6 and 7 ) it could be mentioned that the least susceptible variety was Holland (19.675 and 21.725 insects/sample for $E$. decedens ,14.65and 18.275 insects /sample for E. decipiens ; 13.725 and 20.6 insects/sample for C. china), followed by Escandarani variety (23.75 and 27.225 insects/sample for $E$. decedenss ,18.5 and 21.4 insects /sample for $E$. decipiens ; 17.3 and 27.2 insects/sample for C. china during 2006 and 2007seasons, respectively, whereas the highest population density was recorded on Top Kapi variety (26.225 and 30.975 insects/sample for $E$. decedens ,21.425and 26.45 insects /sample for E. decipiens and 20.275 and 35.5 insects/sample for $C$. china during 2006 and 2007 seasons, respectively).

\section{c) Whitefly insects}

As seen in Tables (6 and 7) the lowest mean number of whitefly insects B. tabaci was recorded on Holland variety (112.775 and 140.525 insects/sample), followed by Escandarani variety (148.35 and 181.45 insects/sample), whereas the highest population density was recorded on Top Kapi variety (154.45 and 214.0 insects/sample) for 2006 and 2007 seasons, respectively. 
Hegab, Ola I. M. and A. M. S. Hegab

$6+7$ 
Generally, from the obtained results, it could be concluded that Top Kapi variety was more susceptible to aphids, leafhoppers and whitefly insects infestation, whereas Holland variety was the least susceptible variety.

Statistical analysis indicated that the differences between the mean number of aphids, leafhoppers and whitefly insects infesting the different varieties of cucumber and squash plants were significant during 2006 and 2007 seasons .These results agreed with the findings of Hector et al ,2008 who found that there are differences between cucumber and squash varieties for homopterous insect infestation and their resistance for plant diseases

\subsubsection{Effect of potassium fertilization.}

Effect of different potassium fertilization levels on the population density of aphids, leafhoppers and whitefly insects infesting cucumber and squash plants was studied and the results are shown in Tables (8 and 9)

\section{l)Cucumber plants}

\section{a) Aphid insects}

Results in Tables (8 and 9) show indicated that the highest mean number of aphid insects infesting cucumber plants (60.266 and 99.966 insects/sample for $A$. gossypii 71.566 and 93.933 insects/sample for $M$. persicae) recorded with "zero potassium fertilization /feddan" during 2006 and 2007 seasons, respectively, while the lowest mean number of aphid insects (45.633 and 81.933 insects /sample for A. gossypii, 58.466 and 77.766 insects/sample for M. persicae) occurred with " $200 \mathrm{~kg}$ potassium sulphate /feddan" during the both seasons, respectively.

\section{b) Leafhopper insects}

According to data in Tables (8 and 9) the highest mean number of leafhopper insects infesting cucumber plants (19.366and 25.366 insects/sample for E. decedens, 16.4 and 23.5 insects/sample for $E$. decipiens and 12.066 and 20.60 insects/sample for C. china) occurred with "zero potassium fertilization /feddan" during 2006 and 2007 seasons, respectively, while the lowest mean number of leafhopper insects (12.133 and 16.4 insects/sample for $E$. decedens,9.566 and 13.766 insects/sample for $E$. decipiens and 8.1 and 12.366 insects/sample for $C$. china) was recorded with "200 kg potassium sulphate /feddan" during the both seasons, respectively.

\section{c)Whitefly insects}

As seen in Tables ( 8 and9),the highest mean number of whitefly insects infesting cucumber plants (250.881 and 316.287insects/sample) was recorded with " zero potassium fertilization /feddan"during 2006 and 2007 seasons, respectively, while the lowest mean number of whitefly insects (179.296 and 218.502 insects/sample) occurred with " $200 \mathrm{~kg}$ potassium sulphate /feddan "during the both seasons, respectively.

\section{II)Squash plants}

\section{a) Aphid insects}

According to data in Tables ( 8 and 9),the highest mean number of aphid insects infesting squash plants(127.3 and 172.3 insects/sample for $A$. gossypii, 155.666and 192.266 insects/sample for M. persicae) were recorded with " zero potassium fertilization /feddan" during 2006 and 2007 seasons, 
respectively, while the lowest mean number of aphid insects (93.9 and 130.866 insects/sample for $A$. gossypii, 123.533 and 146.633 insects/sample for M. persicae)occurred with "200 kg potassium sulphate /feddan" during the both seasons, respectively.

\section{b) Leafhopper insects}

Results in Tables (8and 9) showed that the highest mean number of leafhopper insects infesting squash plants $(29.266$ and 32.766 insects/sample for $E$. decedens,23.6and 27.9 insects/sample for $E$. decipiens and 22.1 and 34.466insects/sample for C.china)occurred with "zero potassium fertilization /feddan" during 2006 and 2007 seasons, respectively, while the lowest mean number of leafhopper insects (17.8 and 20.466 insects/sample for $E$ decedens,13.266 and 16.2 insects/sample for E. decipiens and 12.633 and 21.6 insects/sample for C.china))was recorded with "200 kg potassium sulphate /feddan "during the both seasons, respectively.

c) Whitefly insects

As shown in Tables ( 8 and 9), it could be mentioned that the highest mean number of whitefly insects infesting squash plants (164.639and 207.005 insects/sample) was recorded with "zero potassium fertilization/feddan "during 2006 and 2007 seasons, respectively, while the lowest mean number of whitefly insects (104.906 and 137.087 insects/sample) occurred with " $200 \mathrm{~kg}$ potassium sulphate /feddan" during the both seasons, respectively.

Statistical analysis indicated that the effect of the different potassium fertilization levels on the population density of aphids, leafhoppers and whitefly insects infesting cucumber and squash plants were significant during 2006 and 2007 seasons .

In general, it could be concluded that the potassium fertilization levels influenced pronouncedly on the population density of the aforemention homopterous insects infesting cucumber and squash plants as the results show, that the highest mean number of insects was recorded with the least level of potassium fertilization treatment (zero $\mathrm{kg}$ potassium sulphate/feddan), while increasing this level to $200 \mathrm{~kg}$ potassium fertilization/feddan reduced markedly the insect infestation. Therefore it could be recommended that fertilization with $200 \mathrm{~kg}$ potassium fertilization/feddan is very suitable to decrease the aforementioned insects infestation. These results are in agreement with the finding of Hashem, 2005 and Youssef, 2006.

3.4Relationship between certain chemical constituents of cucumber and squash varieties and infestation with aphids, leafhoppers and whitefly insects

Data given in Tables (10 and 11) indicated that the effects of different chemical constituents of cucumber and squash varieties on the population density of aphids, leafhoppers and whitefly insects were significant.

\subsubsection{Cucumber plants}

I)Protien "P.C." ,Carbohydrates contents "C.C." and pH values

The results showed negatively relationship between protein, carbohydrate contents and $\mathrm{pH}$ values with aphids, leafhoppers and whitefly insects infestation in all three cucumber varieties. 
J. Agric. Sci. Mansoura Univ., 34 (3), March, 2009

$8+9$ 
Hegab, Ola I. M. and A. M. S. Hegab

10

2148 
J. Agric. Sci. Mansoura Univ., 34 (3), March, 2009 
Data in Table (10) showed that in case of Indian variety the mean number of aphids, leafhoppers and whitefly/ sample was 155,54.7 and 260.77 with control zero potassium fertilization $(0.50 \%$ p.c., 2.4 C.C and $5.8 \mathrm{pH}$ ,respectively) and it decreased to 122.8,32.4 and 179.0 insects / sample for aphids, leafhoppers and whitefly, respectively by increasing the protein , carbohydrate content and $\mathrm{pH}$ value to $0.80,3.7$ and 7.0 , respectively with $200 \mathrm{~kg}$ potassium fertilization/feddan. The same trend was recorded on Japanese and Alpha beta varieties .

II) Phosphorous , Potassium and Calcium:

Statistical analysis of obtained data showed that effect of phosphorous, potassium and calcium percentages in cucumber plant varieties on insect infestation was not significant (Table 10).

From the obtained results Indian variety was the lowest in total protein, carbohydrate contents and the highest $\mathrm{pH}$ value, was also the least susceptible to the aforementioned insect's infestation.

It is worth to mention that aphids, leafhoppers and whitefly insects infestation was correlated with the chemical constituents of the used cucumber varieties.

\subsubsection{Squash plants}

I)Protien "P.C.",Carbohydrates contents "C.C." and pH values

The results showed negatively relationship between protein, carbohydrate contents and $\mathrm{pH}$ values with aphids, leafhoppers and whitefly insects infestation in all three squash varieties.

As seen in Table (11) ,the lowest mean number of insects was recorded on Holland variety (277.54, 77.7 and 168.35 insects/sample, for aphids, leafhoppers and whitefly insects respectively with 0.51 total protein, 2.4C.C. and $5.4 \mathrm{pH}$. in control treatment (without potassium fertilization) ,followed by Escandarani variety (333.9,95.6 and 209.87 insects/sample ,for aphids, leafhoppers and whitefly insects, respectively with 0.54 total protein, 2.7C.C. and $5.6 \mathrm{pH}$. with control treatment, while the highest mean number of the aforementioned insects was observed in Top Kapi variety with 0.58 total protein ,2.8C.C. and 5.9pH. (382.81, 112.1 and 242.79 insects/sample, for aphids, leafhoppers and whitefly insects, respectively.

It is worth to mention that the mean number of the aforementioned insects was decreased gradually by increasing the rate of potassium fertilization for the three tested squash varieties, whereas the mean number of insects occurred on Holland variety was 223.45,45.3 and 104.92 for aphids, leafhoppers and whitefly insects, respectively with 0.76P.C.,3.9C.C. and $6.8 \mathrm{pH}$ at $200 \mathrm{~kg}$ potassium fertilization/feddan,followed by Escandarani and Top Kapi varieties at $200 \mathrm{~kg}$ potassium fertilization/feddan $260.44,293.18$ for aphids,56.1,73.4 for leafhoppers and 138.92,167.4 for whitefly with 0.78P.C. ,0.81 P.C. ,4.0C.C., 4.1C.C. and 6.9pH, 7.0pH on Escandarani variety and Top Kapi variety, respectively .

II) Phosphorous, Potassium and Calcium:

Statistical analysis of obtained data showed that effect of phosphorous, potassium and calcium percentages in squash plant varieties was not significant (Table 11). 
From the obtained results Top Kapi variety was the highest total protein, carbohydrate contents and the highest $\mathrm{pH}$ value, the least susceptible to the aforementioned insect's infestation.

Generally, chemical analysis of the used cucumber and squash varieties with different levels of potassium fertilization confirmed that aphids ,leafhoppers and whitefly insects infestation was negatively related with protein, carbohydrate contents and $\mathrm{pH}$ values.

It is worth to mention that under field condition with zero potassium fertilization/feddan insects infestation positively correlated with P.C. and C.C. in different cucumber and squash varieties, while negative correlation was recorded in case of $\mathrm{pH}$ values and insects infestation .

These results agreed with those recorded by Moran and Schultz ,(1998); Fredric et al., (2006); El Gindy, 2006 and Hegab ,2008) who mentioned similar trends on other plants.

\section{REFERENCES}

Barrowes,L.H.and E.C.Simpson (1962):A method for the direct routine determination of calcium and magnesium in soil and plant tissues .Soil Soc.Amr.Proc.26:443-445.

Berlandier, F. A. ; D. J .Thackray; A. C.Jonesr.; J. Lathaml. and L. Cartwright, (1997): Determining the relative roles of different aphid species as vectors of cucumber mosaic and bean yellow mosaic viruses in lupines. Annals of applied biology, vol. 131, (2) : 297-314

Berry, R. E. (1998): Insect and mites of economic importance in the Pacific Northwest, 2nd Ed. OSU Bookstore, Inc.Corvallis, OR, USA. 221 pp.

Bremmer , J.M. and C.S.Mulvaney (1982):Total Nitrogen (c.i Page, A.L.; R.H.Miller and D.R.Keeney (Eds): Methods of soil analysis, part 2Amer. Soc.: 595-624.

David,B.A.(2008): insect managment .http//pubs.caes.uga edu/ casespubs/ pub cd/b1178.htm

Dubois,M.;K. Giles; J.K. Hamilton; P. A. Rebvsand F. Smith (1956): Colorimetric method for determination of sugars and related compounds. Anal. Chem., 28:350-356.

El Gindy,M.A.(2006):Susceptibility of three maize cultivars to leafhoppers infestation and effect of potassium fertilizer levels on leafhoppers.Egypt,J.of Appl. Sci. Vol.21(10A):302-314.

Frédéric F.; G.Pascal; H.Nicolas; M.Gabriel; D. P. Edwin and H. Eric (2006):Protoeomics in Myzus persicae Effect of aphid host plant . Insect Biochemistry and Molecular Biology, Vol. 36( 3) : 219-227.

Hashem,M.S.(2005): Studies on certain piercing sucking insects infesting some vegetable crop.Ph.D Thesis, Fac.Agric. Moshtohour Zagazig Univ.

Hegab,M. A. M.(2008):Studies on certain homopterous insect vectors of phytopathogenic diseases M.Sc.Thesis Fac.of Agric.Zagazig Univ. 
Hegab, A. M.; M. M. El-Zohairy; M. M. Helaly and H. M. El- Sharkawy (1989a) : Survey and seasonal abundance of leafhoppers infesting certain solanaceous vegetable plants in newly reclaimed sandy areas at Salhia district, Egypt. Zagazig J. Agric. Res., 16(2): 175-187.

Hegab,A.M.; M.M.Helaly and S.S.M.Hassanein (1989b): Survey and Seasonal abundance of leafhopper species (Homoptera: cicadellidae) infesting certain cruciferous and cucurbitaceous vegetable plants in newly reclaimed sandy areas at Salhia district, Egypt .Zagazig J.Agric. Res. Vol.16 (1).

Hegab-Ola,I.M.S.(2001):Studies on certain insect vectors of plant pathogenic agents .Ph.D. Thesis Fac. Agric .Zagazig Univ.

Hector,V.R.; T.H.Randall, and F.Steve, (2008): Cucumber production guidelines. University of Hawaii. Field Cucumber Production Guidelines.htm

Hunter,J. and Jr. Gray(2008):Greenhouse cucumber production. Univ. Of Calf. ,Texas Hydroponics Greenhouse Cucumber Production.htm

Kozma, E. ; G.Gólya , and M. Czinder, (2001): Yellow mosaic virus and its vectors in cucumber in Western Hungary: Acta Phytopath. Entomol. Hungary , Vol. 36, (3-4), : 359-364(6)

Little,T.M.and F.J.Hills(1975):Statistical methods in agricultural research .Ued Book Store Univ. of Califorinia ,Davis 242p.

Moran, P. J.and J. C.Schultz, (1998) : Ecological and Chemical associations among late-season squash pests Environmental Entomology, Vol. $27, N(1): 39-44$.

Neilson,M.W.(1968):The leafhopper vectors of phytopathogenic viruses (Homoptera: Cicadellidae) taxonomy, biology and virus transmission .Agric .Ser .M.S.Dept.Agr.89. pp386.

Raupach ,K.; C.Borgemeister; M. Hommes,; H. M. Poehling and M. Sétamou, (2002):Effect of temperature and host plants on the bionomics of Empoasca decipiens (Homoptera: Cicadellidae) Hannover, Germany http//wwwScience direct.com .

Webb,S.E.(2007): Insect management for cucurbits (cucumber squash, cantaloupe and watermelon). http//edis.ifas ufl.Youssef,A.A.A.(2006): Studies on some homopterous insect vectors of plant disease. Ph.D Thesis, Fac.of Agric.Zagazig Univ. 


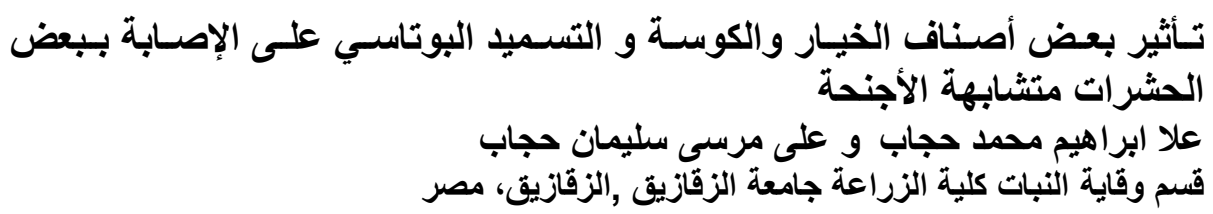

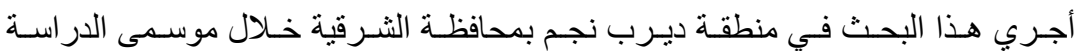

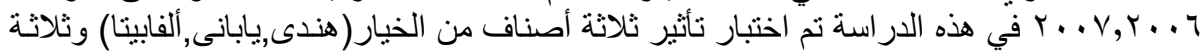

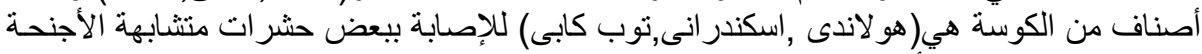

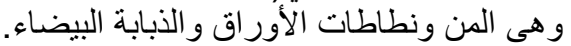

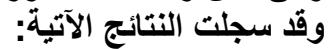

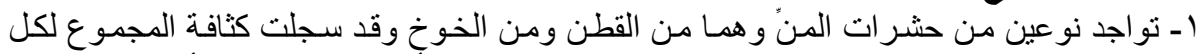

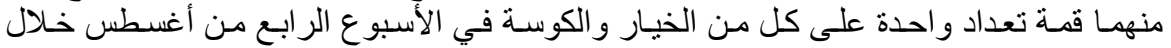

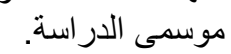
rاتواجد ثمانية أنواع من نطاطات الأوراق على كل من الخيار و الكوسة وأن أكثر الأنواع السائدة من حشر ات نطاطات الأوراق هى

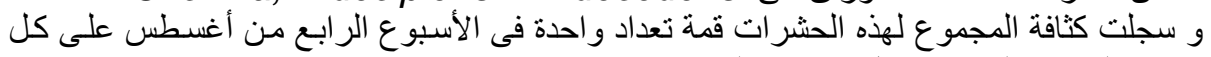

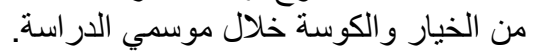

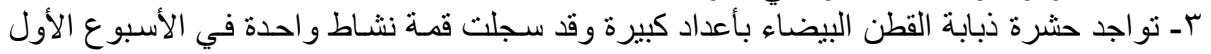

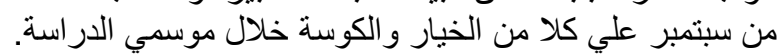

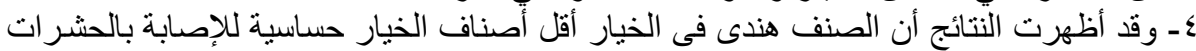

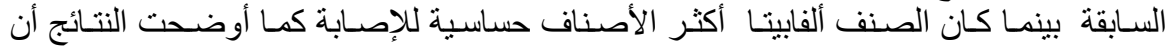

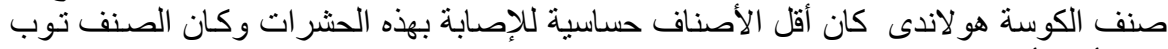

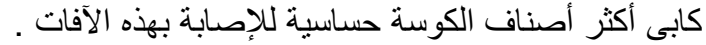

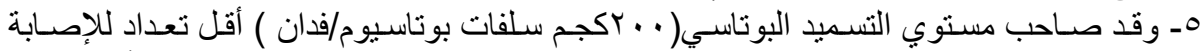

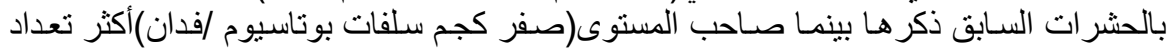

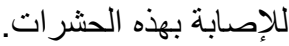

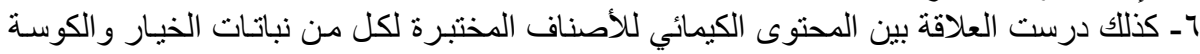

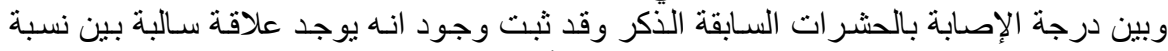

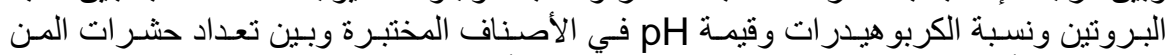
ونطاطات الأوراق والذبابة البيضاء التي تصيب تلثين تلك الأصناف. 
Table(1):Total number of aphids ,leafhoppers and whitefly insects species collected from some cucumber and squash plant varieties at Diarb-Nigm district,Sharkia Governorate during 2006 and 2007 seasons.

\begin{tabular}{|c|c|c|c|c|c|c|c|}
\hline \multirow{3}{*}{$\begin{array}{l}\text { Insects } \\
\text { species }\end{array}$} & \multirow{3}{*}{ Seasons } & \multicolumn{6}{|c|}{ Total number of insects } \\
\hline & & \multicolumn{3}{|c|}{ Cucumber } & \multicolumn{3}{|c|}{ Squash } \\
\hline & & Indian & Japanese & Alpha beta & Holland & Escandarani & Top Kapi \\
\hline \multirow[t]{2}{*}{ Aphis gossypii } & 2006 & 5043 & 6114 & 7815 & 10893 & 12408 & 16539 \\
\hline & 2007 & 8292 & 10686 & 13689 & 14190 & 18075 & 22218 \\
\hline \multirow{2}{*}{\begin{tabular}{|l|} 
Myzus \\
persicae
\end{tabular}} & 2006 & 5697 & 8139 & 9579 & 14199 & 17088 & 18897 \\
\hline & 2007 & 8349 & 10053 & 12465 & 17718 & 21141 & 22713 \\
\hline \multirow{2}{*}{$\begin{array}{l}\text { Empoasca } \\
\text { decedens }\end{array}$} & 2006 & 1398 & 1887 & 2397 & 2361 & 2850 & 3147 \\
\hline & 2007 & 2064 & 2511 & 2937 & 2607 & 3267 & 3717 \\
\hline \multirow[t]{2}{*}{ E.decipiens } & 2006 & 1041 & 1635 & 2010 & 1758 & 2220 & 2571 \\
\hline & 2007 & 1656 & 2214 & 2763 & 2193 & 2568 & 3170 \\
\hline \multirow{2}{*}{$\begin{array}{l}\text { Cicadulina } \\
\text { chinai }\end{array}$} & 2006 & 972 & 1206 & 1404 & 1647 & 2076 & 2433 \\
\hline & 2007 & 1446 & 1944 & 2523 & 2472 & 3264 & 4260 \\
\hline \multirow[t]{2}{*}{ E. distinguend } & 2006 & 8 & 11 & 14 & 7 & 10 & 13 \\
\hline & 2007 & 10 & 13 & 16 & 9 & 12 & 17 \\
\hline \multirow{2}{*}{$\begin{array}{l}\text { Nephotettix } \\
\text { apicalis }\end{array}$} & 2006 & 13 & 18 & 21 & 15 & 18 & 20 \\
\hline & 2007 & 17 & 22 & 25 & 19 & 23 & 25 \\
\hline \multirow{4}{*}{\begin{tabular}{|l|} 
Balclutha \\
hortensis \\
E. lybica \\
\end{tabular}} & 2006 & 16 & 22 & 25 & 14 & 17 & 18 \\
\hline & 2007 & 20 & 25 & 28 & 19 & 20 & 22 \\
\hline & 2006 & 7 & 9 & 14 & 8 & 10 & 13 \\
\hline & 2007 & 10 & 13 & 15 & 11 & 13 & 17 \\
\hline \multirow{2}{*}{\begin{tabular}{|l} 
Circulifora \\
tenellus
\end{tabular}} & 2006 & 9 & 12 & 14 & 10 & 12 & 15 \\
\hline & 2007 & 11 & 15 & 16 & 11 & 15 & 17 \\
\hline \multirow[t]{2}{*}{ Bemisia tabaci } & 2006 & 22533 & 27975 & 33528 & 13533 & 17802 & 18534 \\
\hline & 2007 & 27486 & 32643 & 40137 & 16863 & 21774 & 25680 \\
\hline
\end{tabular}


Table(2):Total numbers of aphids Aphis gossypii(Glov.),Myzus persicae( Sulzer), leafhoppers Empoasca decedens (Paoli), E. decipiens (Paoli), Cicadulina chinai(Ghauri)and whiteflyBemisia tabaci (Genn.) infesting cucumber plants at Diarb-Nigm district, Sharkia Governorate, Egypt during 2006 season.

\begin{tabular}{|c|c|c|c|c|c|c|c|c|c|c|}
\hline \multirow{3}{*}{\begin{tabular}{|c|}
$\begin{array}{c}\text { Date of } \\
\text { inspection } \\
\text { (weekly) }\end{array}$ \\
\end{tabular}} & \multicolumn{10}{|c|}{ Number of insects/sample } \\
\hline & \multirow{2}{*}{ A. gossypii } & \multirow{2}{*}{ M. persicae } & \multirow{2}{*}{ E. decedens } & \multirow{2}{*}{ E. decipiens } & \multirow{2}{*}{ C. chinai } & \multicolumn{2}{|c|}{ Whitefly B.tabaci } & \multirow{2}{*}{ Total } & \multicolumn{2}{|c|}{ Means } \\
\hline & & & & & & adult & immature & & Temp.C ${ }^{\circ}$ & R.H.\% \\
\hline \begin{tabular}{|l} 
July $1^{\text {st }}$ \\
to
\end{tabular} & 0 & 0 & 0 & 0 & 0 & 0 & 0 & 0 & 31.4 & 65.0 \\
\hline $2^{\text {nd }}$ & 0 & 0 & 0 & 0 & 0 & 0 & 0 & 0 & 30.6 & 65.7 \\
\hline $3^{\text {rd }}$ & 2 & 1 & 1 & 1 & 1 & 14 & 9 & 23 & 30.4 & 67.7 \\
\hline $4^{\text {th }}$ & 15 & 12 & 6 & 4 & 2 & 33 & 21 & 54 & 29.9 & 67.0 \\
\hline Aug. $1^{\text {st }}$ & 23 & 41 & 15 & 7 & 6 & 77 & 44 & 121 & 30.2 & 67.5 \\
\hline $2^{\text {nd }}$ & 40 & 84 & 19 & 10 & 14 & 95 & 95 & 190 & 30.2 & 66.2 \\
\hline $3^{\text {rd }}$ & 67 & 102 & 21 & 17 & 16 & 116 & 178 & 294 & 30.9 & 66.8 \\
\hline $4^{\text {th }}$ & 112 & 137 & 27 & 26 & 21 & 171 & 205 & 376 & 30.4 & 65.4 \\
\hline Sep. $1^{\text {st }}$ & 83 & 83 & 22 & 21 & 17 & 161 & 281 & 441 & 28.0 & 62.5 \\
\hline $2^{\text {nd }}$ & 71 & 43 & 17 & 16 & 12 & 114 & 227 & 341 & 29.8 & 64.2 \\
\hline $3^{\text {rd }}$ & 55 & 22 & 12 & 8 & 7 & 74 & 176 & 250 & 29.1 & 64.0 \\
\hline $4^{\text {th }}$ & 21 & 9 & 4 & 2 & 1 & 39 & 88 & 127 & 28.7 & 61.5 \\
\hline Total & 489 & 534 & 144 & 112 & 97 & 894 & 1324 & 2220 & & \\
\hline
\end{tabular}


Table(3):Total numbers of aphids A. gossypii(Glov.),Myzus persicae ( Sulzer), leafhoppers Empoasca decedens (Paoli), E. decipiens (Paoli), C. chinai(Ghauri )and whitefly Bemisia tabaci (Genn.) infesting cucumber plants at Diarb-Nigm district, Sharkia Governorate, Egypt during 2007 season.

\begin{tabular}{|c|c|c|c|c|c|c|c|c|c|c|}
\hline \multirow{3}{*}{$\begin{array}{c}\text { Date of } \\
\text { inspection } \\
\text { (weekly) }\end{array}$} & \multicolumn{10}{|c|}{ Number of insects/sample } \\
\hline & \multirow{2}{*}{ A. gossypii } & \multirow{2}{*}{ M. persicae } & \multirow{2}{*}{ E. decedens } & \multirow{2}{*}{ E. decipiens } & \multirow{2}{*}{ C. chinai } & \multicolumn{2}{|c|}{ Whitefly B.tabaci } & \multirow{2}{*}{ Total } & \multicolumn{2}{|c|}{ Means } \\
\hline & & & & & & adult & immature & & Temp.C ${ }^{\circ}$ & R.H.\% \\
\hline \begin{tabular}{|l} 
July $1^{\text {st }}$ \\
\end{tabular} & 0 & 0 & 0 & 0 & 0 & 0 & 0 & 0 & 30.9 & 65.2 \\
\hline $2^{\text {nd }}$ & 0 & 0 & 0 & 0 & 0 & 0 & 0 & 0 & 31.2 & 64.7 \\
\hline $3^{\text {rd }}$ & 4 & 1 & 1 & 1 & 1 & 13 & 9 & 22 & 31.5 & 63.5 \\
\hline $4^{\text {th }}$ & 33 & 18 & 9 & 7 & 3 & 29 & 54 & 83 & 33.2 & 67.1 \\
\hline Aug. 1 $^{\text {st }}$ & 65 & 58 & 19 & 15 & 10 & 68 & 97 & 165 & 31.9 & 67.4 \\
\hline $2^{\text {nd }}$ & 126 & 95 & 28 & 22 & 20 & 95 & 148 & 243 & 31.7 & 69.5 \\
\hline $3^{\text {rd }}$ & 210 & 123 & 36 & 30 & 30 & 169 & 214 & 383 & 31.8 & 67.0 \\
\hline $4^{\text {th }}$ & 288 & 195 & 43 & 38 & 35 & 217 & 276 & 493 & 31.2 & 65.5 \\
\hline Sep. $1^{\text {st }}$ & 210 & 151 & 29 & 30 & 22 & 185 & 363 & 548 & 32.3 & 67.1 \\
\hline $2^{\text {nd }}$ & 153 & 82 & 20 & 21 & 18 & 152 & 270 & 422 & 29.5 & 64.5 \\
\hline $3^{\text {rd }}$ & 97 & 31 & 15 & 15 & 11 & 75 & 157 & 232 & 29.6 & 64.7 \\
\hline $4^{\text {th }}$ & 58 & 17 & 5 & 7 & 6 & 31 & 77 & 108 & 28.9 & 65.0 \\
\hline Total & 1244 & 771 & 205 & 186 & 156 & 1034 & 1665 & 2699 & & \\
\hline
\end{tabular}


Table(4): Total numbers of aphids A. gossypii(Glov.),Myzus persicae ( Sulzer), leafhoppers Empoasca decedens (Paoli), E. decipiens (Paoli), C. chinai (Ghauri)and whiteflyBemisia tabaci (Genn.) infesting squash plants at Diarb-Nigm district, Sharkia Governorate, Egypt during 2006 season.

\begin{tabular}{|c|c|c|c|c|c|c|c|c|c|c|}
\hline \multirow{3}{*}{\begin{tabular}{|c|} 
Date of \\
inspection \\
(weekly)
\end{tabular}} & \multicolumn{8}{|c|}{ Number of insects/sample } & \multirow{3}{*}{ Temp. $\mathbf{C}^{\circ}$} & \multirow{3}{*}{ R.H.\% } \\
\hline & \multirow{2}{*}{ A. gossypii } & \multirow{2}{*}{ M. persicae } & \multirow{2}{*}{ E. decedens } & \multirow{2}{*}{ E. decipiens } & \multirow{2}{*}{ C. chinai } & \multicolumn{2}{|c|}{ Whitefly B.tabaci } & \multirow{2}{*}{ Total } & & \\
\hline & & & & & & adult & immature & & & \\
\hline July $1^{\text {st }}$ & 0 & 0 & 0 & 0 & 0 & 0 & 0 & 0 & 31.4 & 65.0 \\
\hline $2^{\text {nd }}$ & 0 & 0 & 0 & 0 & 0 & 0 & 0 & 0 & 30.6 & 65.7 \\
\hline $3^{\text {rd }}$ & 15 & 16 & 1 & 1 & 1 & 7 & 2 & 9 & 30.4 & 67.7 \\
\hline $4^{\text {th }}$ & 45 & 55 & 9 & 8 & 8 & 11 & 9 & 20 & 29.9 & 67.0 \\
\hline Aug. $1^{\text {st }}$ & 80 & 92 & 19 & 17 & 13 & 23 & 28 & 51 & 30.2 & 67.5 \\
\hline $2^{\text {nd }}$ & 120 & 140 & 29 & 23 & 21 & 53 & 52 & 105 & 30.2 & 66.2 \\
\hline $3^{\text {rd }}$ & 150 & 205 & 38 & 30 & 29 & 87 & 84 & 171 & 30.9 & 66.8 \\
\hline $4^{\text {th }}$ & 190 & 240 & 49 & 38 & 37 & 123 & 135 & 258 & 30.4 & 65.4 \\
\hline Sep. $1^{\text {st }}$ & 170 & 193 & 40 & 31 & 29 & 113 & 184 & 297 & 28.0 & 62.5 \\
\hline $2^{\text {nd }}$ & 140 & 175 & 32 & 21 & 19 & 72 & 163 & 235 & 29.8 & 64.2 \\
\hline $3^{\text {rd }}$ & 90 & 140 & 22 & 14 & 14 & 24 & 115 & 139 & 29.1 & 64.0 \\
\hline $4^{\text {th }}$ & 35 & 79 & 13 & 7 & 8 & 12 & 81 & 93 & 28.7 & 61.5 \\
\hline Total & 1035 & 1335 & 252 & 190 & 179 & 525 & 853 & 1378 & & \\
\hline
\end{tabular}


Table(5): Total numbers of aphids A. gossypii(Glov.),Myzus persicae ( Sulzer), leafhoppers Empoasca decedens (Paoli), E.decipiens (Paoli), C. chinai( Ghauri)and whiteflyBemisia tabaci (Genn.) infesting squash plants at Diarb-Nigm district, Sharkia Governorate, Egypt during 2007 season.

\begin{tabular}{|c|c|c|c|c|c|c|c|c|c|c|}
\hline \multirow{3}{*}{$\begin{array}{c}\text { Date of } \\
\text { inspection } \\
\text { (weekly) }\end{array}$} & \multicolumn{8}{|c|}{ Number of insects/sample } & \multirow{3}{*}{ Temp. $C^{\circ}$} & \multirow{3}{*}{ R.H.\% } \\
\hline & \multirow{2}{*}{ A gossypii } & \multirow{2}{*}{ M persicae } & \multirow{2}{*}{ E decedens } & \multirow{2}{*}{ E decipiens } & \multirow{2}{*}{ C. chinai } & \multicolumn{3}{|c|}{ Whitefly B.tabaci } & & \\
\hline & & & & & & adult & immature & Total & & \\
\hline July $1^{\text {st }}$ & 0 & 0 & 0 & 0 & 0 & 0 & 0 & 0 & 30.9 & 65.2 \\
\hline $2^{\text {nd }}$ & 0 & 0 & 0 & 0 & 0 & 0 & 0 & 0 & 31.2 & 64.7 \\
\hline $3^{\text {rd }}$ & 20 & 20 & 2 & 1 & 1 & 9 & 2 & 11 & 31.5 & 63.5 \\
\hline $4^{\text {th }}$ & 80 & 66 & 11 & 9 & 12 & 16 & 16 & 32 & 33.2 & 67.1 \\
\hline Aug. $1^{\text {st }}$ & 150 & 142 & 22 & 19 & 22 & 33 & 54 & 87 & 31.9 & 67.4 \\
\hline $2^{\text {nd }}$ & 180 & 189 & 31 & 26 & 32 & 64 & 87 & 151 & 31.7 & 69.5 \\
\hline $3^{\text {rd }}$ & 220 & 256 & 41 & 36 & 41 & 96 & 136 & 232 & 31.8 & 67.0 \\
\hline $4^{\text {th }}$ & 270 & 317 & 56 & 47 & 52 & 144 & 182 & 326 & 31.2 & 65.5 \\
\hline Sep. $1^{\text {st }}$ & 200 & 275 & 46 & 40 & 40 & 122 & 236 & 358 & 32.3 & 67.1 \\
\hline $2^{\text {nd }}$ & 120 & 208 & 32 & 29 & 30 & 87 & 191 & 278 & 29.5 & 64.5 \\
\hline $3^{\text {rd }}$ & 85 & 125 & 22 & 18 & 20 & 58 & 105 & 163 & 29.6 & 64.7 \\
\hline $4^{\text {th }}$ & 39 & 84 & 15 & 9 & 17 & 23 & 80 & 103 & 28.9 & 65.0 \\
\hline Total & 1364 & 1682 & 278 & 234 & 267 & 652 & 1089 & 1741 & & \\
\hline
\end{tabular}


Table (6): Mean number of aphids, leafhoppers and whitefly insects infesting different varieties of cucumber and squash plants at Diarb-Nigm district,Sharkia Governorate during 2006 season.

\begin{tabular}{|c|c|c|c|c|c|c|c|c|c|}
\hline \multirow[t]{3}{*}{ plant } & \multirow{3}{*}{\begin{tabular}{|l} 
Varieties \\
Insects
\end{tabular}} & \multicolumn{8}{|c|}{ Mean number of insects/sample } \\
\hline & & \multirow{2}{*}{ A. gossypii } & \multirow{2}{*}{ M. persicae } & \multirow{2}{*}{ E. decedens } & \multirow{2}{*}{ E. decipiens } & \multirow{2}{*}{ C. chinai } & \multicolumn{2}{|c|}{ B. tabaci } & \multirow[t]{2}{*}{ Total } \\
\hline & & & & & & & Adult & immature & \\
\hline \multirow[t]{3}{*}{ Cucumber } & Indian & 42.025 & 47.475 & 11.65 & 8.675 & 8.1 & 76.375 & 111.4 & 187.775 \\
\hline & \begin{tabular}{|l|} 
Japanese \\
\end{tabular} & 50.95 & 67.125 & 15.725 & 13.625 & 10.05 & 86.5 & 146.625 & 233.125 \\
\hline & Alph beta & 65.125 & 79.825 & 19.975 & 16.75 & 11.7 & 99.45 & 179.95 & 279.4 \\
\hline \multirow[t]{3}{*}{ Squash } & Holland & 90.775 & 118.325 & 19.675 & 14.65 & 13.725 & 44.275 & 68.5 & 112.775 \\
\hline & Escandarani & 103.4 & 142.4 & 23.75 & 18.5 & 17.3 & 61.925 & 86.425 & 148.35 \\
\hline & Top Kapi & 137.825 & 157.475 & 26.225 & 21.425 & 20.275 & 63.35 & 91.1 & 154.45 \\
\hline $\mathbf{F}$ & & * & * & * & * & * & & & 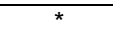 \\
\hline
\end{tabular}

N.B. ${ }^{*} F$ value is significant at $p>0.05$

Table (7): Mean number of aphids, leafhoppers and whitefly insects infesting different varieties of cucumber and squash plants at Diarb-Nigm district,Sharkia Governorate during 2007season.

\begin{tabular}{|c|c|c|c|c|c|c|c|c|c|}
\hline \multirow[t]{3}{*}{ plant } & \multirow{3}{*}{\begin{tabular}{|l} 
varieties \\
insects
\end{tabular}} & \multicolumn{8}{|c|}{ Mean number of insects/sample } \\
\hline & & \multirow{2}{*}{ A gossypii } & \multirow{2}{*}{ M. persicae } & \multirow{2}{*}{ E. decedens } & \multirow{2}{*}{ E. decipiens } & \multirow{2}{*}{ C chinai } & \multicolumn{2}{|c|}{ B. tabaci } & \multirow[t]{2}{*}{ Total } \\
\hline & & & & & & & Adult & immature & \\
\hline \multirow[t]{3}{*}{ Cucumber } & Indian & 69.1 & 69.575 & 17.2 & 13.8 & 12.05 & 84.925 & 144.125 & 229.05 \\
\hline & \begin{tabular}{|l|} 
Japanese \\
\end{tabular} & 89.05 & 83.775 & 20.925 & 18.45 & 16.2 & 100.475 & 171.55 & 272.025 \\
\hline & Alph beta & 114.075 & 103.875 & 24.475 & 23.025 & 21.025 & 121.925 & 212.55 & 334.475 \\
\hline \multirow[t]{3}{*}{ Squash } & Holland & 118.25 & 147.65 & 21.725 & 18.275 & 20.6 & 52.375 & 88.15 & 140.525 \\
\hline & Escandarani & 150.625 & 176.175 & 27.225 & 21.4 & 27.2 & 72.2 & 109.25 & 181.45 \\
\hline & Top Kapi & 185.15 & 189.275 & 30.975 & 26.45 & 35.5 & 79.55 & 134.45 & 214.0 \\
\hline $\mathrm{F}$ & & * & ${ }^{*}$ & $\star$ & * & * & & & * \\
\hline
\end{tabular}

N.B. $\quad{ }^{*} \mathrm{~F}$ value is significant at $p>0.05$ 
Table (8): Effect of different potassium fertilization levels on the mean number of aphids, leafhoppers and whitefly insects infesting cucumber plants and squash plants during 2006 season.

\begin{tabular}{|c|c|c|c|c|c|c|c|c|c|}
\hline \multirow[t]{3}{*}{ plant } & \multirow{3}{*}{\begin{tabular}{|l} 
Insects \\
Fertilization
\end{tabular}} & \multicolumn{8}{|c|}{ Mean number of insects/sample } \\
\hline & & \multirow{2}{*}{ A gossypii } & \multirow{2}{*}{ M. persicae } & \multirow{2}{*}{ E. decedens } & \multirow{2}{*}{ E. decipiens } & \multirow{2}{*}{ C chinai } & \multicolumn{2}{|c|}{ B. tabaci } & \multirow{2}{*}{ Total } \\
\hline & & & & & & & Adult & immature & \\
\hline \multirow[t]{4}{*}{ Cucumber } & $F 1$ & 60.266 & 71.566 & 19.366 & 16.4 & 12.066 & 107.633 & 171.033 & 250.881 \\
\hline & F2 & 54.8 & 66.8 & 16.833 & 14.233 & 10.366 & 93.566 & 156.133 & 241.193 \\
\hline & F3 & 50.1 & 62.4 & 14.8 & 11.866 & 9.266 & 81.1 & 138.833 & 212.560 \\
\hline & F4 & 45.633 & 58.466 & 12.133 & 9.566 & 8.1 & 67.466 & 117.966 & 179.296 \\
\hline \multirow{4}{*}{ Squash } & $\mathrm{F} 1$ & 127.3 & 155.666 & 29.266 & 23.6 & 22.1 & 70.333 & 100.7 & 164.639 \\
\hline & F2 & 115.6 & 144.6 & 24.866 & 19.866 & 18.4 & 62.7 & 89.033 & 146.033 \\
\hline & F3 & 105.866 & 133.8 & 20.933 & 16.033 & 15.266 & 55.066 & 77.0 & 127.06 \\
\hline & F4 & 93.9 & 123.533 & 17.8 & 13.266 & 12.633 & 47.966 & 61.3 & 104.906 \\
\hline $\mathbf{F}$ & & + & * & & * & 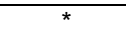 & & & 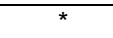 \\
\hline
\end{tabular}

N.B. ${ }^{*} F$ value is significant at $p>0.05$

F1=zero $\mathrm{kg}$ potassium sulphate /feddan $\quad F 2=50 \mathrm{~kg}$ potassium sulphate/feddan

$\mathrm{F} 3=100 \mathrm{~kg}$ potassium sulphate /feddan $\quad F 4=200 \mathrm{~kg}$ potassium sulphate /feddan

Table (9): Effect of different potassium fertilization levels on the mean number of aphids, leafhoppers and whitefly insects infesting cucumber plants and squash plants during 2007 season.

\begin{tabular}{|c|c|c|c|c|c|c|c|c|c|}
\hline \multirow[t]{3}{*}{ plant } & \multirow{3}{*}{\begin{tabular}{|l|} 
Insects \\
Fertilization
\end{tabular}} & \multicolumn{8}{|c|}{ Mean number of insects/sample } \\
\hline & & \multirow{2}{*}{ A gossypii } & \multirow{2}{*}{ M. persicae } & \multirow{2}{*}{ E. decedens } & \multirow{2}{*}{ E. decipiens } & \multirow{2}{*}{ C chinai } & \multicolumn{2}{|c|}{ B. tabaci } & \multirow[t]{2}{*}{ Total } \\
\hline & & & & & & & Adult & immature & \\
\hline \multirow{4}{*}{ Cucumber } & $\mathrm{F} 1$ & 99.966 & 93.933 & 25.366 & 23.5 & 20.6 & 123.7 & 203.833 & 316.287 \\
\hline & F2 & 93.766 & 88.566 & 22.266 & 19.9 & 17.666 & 109.8 & 188.466 & 288.284 \\
\hline & F3 & 87.3 & 82.7 & 19.433 & 16.533 & 15.066 & 96.0 & 166.133 & 253.405 \\
\hline & F4 & 81.933 & 77.766 & 16.4 & 13.766 & 12.366 & 80.266 & 145.533 & 218.502 \\
\hline \multirow[t]{5}{*}{ Squash } & $F 1$ & 172.3 & 192.266 & 32.766 & 27.9 & 34.466 & 81.33 & 133.066 & 207.005 \\
\hline & F2 & 157.6 & 179.2 & 28.933 & 24.0 & 29.7 & 72.466 & 119.133 & 185.011 \\
\hline & F3 & 144.6 & 166.033 & 24.4 & 20.066 & 25.3 & 62.866 & 103.633 & 160.784 \\
\hline & F4 & 130.866 & 146.633 & 20.466 & 16.2 & 21.6 & 55.5 & 86.633 & 137.087 \\
\hline & $F$ & * & * & * & & * & & & \\
\hline
\end{tabular}

N.B. * $F$ value is significant at $p>0.05$

$\mathrm{F} 1=$ zero $\mathrm{kg}$ potassium sulphate /feddan

$\mathrm{F} 2=50 \mathrm{~kg}$ potassium sulphate/feddan

$\mathrm{F} 3=100 \mathrm{~kg}$ potassium sulphate $/ \mathrm{feddan} \quad \mathrm{F} 4=200 \mathrm{~kg}$ potassium sulphate /feddan 
Table(10): Effect of potassium fertilization on protein $\%$, carbohydrate $\%, \mathrm{Ca} \%, \mathrm{pH}, \mathrm{P} \%$ and $\mathrm{K} \%$ of the three cucumber varieties and its relation with certain homopterous insects infestation during 2007 season

\begin{tabular}{|c|c|c|c|c|c|c|c|c|c|c|c|c|c|c|c|c|c|}
\hline \multirow[t]{2}{*}{ variety } & \multirow[t]{2}{*}{ Treatments } & \multirow[t]{2}{*}{ P.C } & \multirow[t]{2}{*}{ C.C } & \multirow[t]{2}{*}{ Са\% } & \multirow[t]{2}{*}{ pH } & \multirow[t]{2}{*}{ P\% } & \multirow[t]{2}{*}{$\mathrm{K} \%$} & \multirow{2}{*}{$\begin{array}{c}\text { A. } \\
\text { gossypii }\end{array}$} & \multirow[t]{2}{*}{$\begin{array}{c}M . \\
\text { persicae }\end{array}$} & \multirow[t]{2}{*}{ Total } & \multirow[t]{2}{*}{$\begin{array}{c}E . \\
\text { decedens }\end{array}$} & \multirow[t]{2}{*}{$\begin{array}{c}E . \\
\text { decipiens }\end{array}$} & \multirow[t]{2}{*}{ C. chinal } & \multirow[t]{2}{*}{ Total } & \multicolumn{2}{|c|}{ whitefly } & \multirow[t]{2}{*}{ Total } \\
\hline & & & & & & & & & & & & & & & Adult & immature & \\
\hline \multirow[t]{4}{*}{ Indian } & zero & 0.50 & 2.4 & 0.032 & 5.8 & 0.16 & 0.2 & 77.9 & 77.1 & 155 & 20.5 & 18.6 & 15.6 & 54.7 & 94.27 & 166.5 & 260.77 \\
\hline & 50 & 0.61 & 2.9 & \begin{tabular}{|l|}
0.034 \\
\end{tabular} & \begin{tabular}{|l|}
6.3 \\
\end{tabular} & 0.15 & 0.22 & 71.6 & 72.4 & \begin{tabular}{|l|}
144 \\
\end{tabular} & 18.2 & 14.9 & 13.1 & 46.2 & 82.54 & 155.2 & 237.74 \\
\hline & 100 & 0.72 & 3.1 & \begin{tabular}{|l|l|}
0.038 \\
\end{tabular} & 6.8 & 0.22 & \begin{tabular}{|l|}
0.31 \\
\end{tabular} & 66.0 & 66.9 & 132.9 & 16.3 & 11.9 & 10.7 & 38.9 & 72.0 & 135.8 & 207.8 \\
\hline & 200 & 0.80 & 3.7 & \begin{tabular}{|l|}
0.036 \\
\end{tabular} & \begin{tabular}{|l|}
7.0 \\
\end{tabular} & 0.10 & \begin{tabular}{|l|}
0.2 \\
\end{tabular} & 60.9 & 61.9 & 122.8 & 13.8 & 9.8 & 8.8 & 32.4 & 60.0 & 119.0 & 179 \\
\hline \multirow[t]{4}{*}{ Japanese } & zero & 0.54 & 2.52 & 0.035 & 6.0 & 0.14 & 0.25 & 98.6 & 92.3 & 190.9 & 25.2 & 23.2 & 20.3 & 68.7 & 112.36 & 199.4 & 311.76 \\
\hline & 50 & 0.65 & 3.1 & 0.037 & 6.4 & 0.08 & 0.24 & 91.8 & 86.8 & 178.6 & 22.1 & 19.8 & 17.3 & 59.2 & 99.0 & 185.2 & 284.2 \\
\hline & 100 & 0.75 & 3.5 & 0.032 & 7.1 & 0.09 & 0.26 & 85.6 & 80.6 & 166.2 & 19.5 & 16.7 & 15.2 & 51.4 & 83.63 & $\begin{array}{l}163.3 \\
\end{array}$ & 246.93 \\
\hline & 200 & 0.82 & 3.9 & \begin{tabular}{|l|}
0.034 \\
\end{tabular} & 7.3 & 0.10 & 0.23 & 80.2 & 75.4 & 155.6 & 16.9 & 14.1 & 12.0 & 43 & 70.36 & 138.3 & 208.66 \\
\hline \multirow[t]{5}{*}{ Alpha beta } & zero & 0.56 & 2.8 & 0.035 & 6.2 & 0.12 & 0.24 & 123.4 & 112.4 & 235.8 & 30.4 & 28.7 & 25.9 & 85 & 130.72 & 246.6 & 377.32 \\
\hline & 50 & 0.69 & 3.4 & 0.037 & 6.7 & 0.15 & 0.26 & 117.9 & 106.5 & 224.4 & 26.5 & 25.0 & 22.6 & 74.1 & 117.9 & 225.0 & 342.9 \\
\hline & 100 & 0.80 & 3.8 & 0.038 & 7.4 & 0.17 & 0.28 & 110.3 & 100.6 & 210.9 & 22.5 & 21.0 & 19.3 & 62.8 & 106.18 & 199.3 & 305.48 \\
\hline & 200 & 0.88 & 4.1 & 0.035 & 7.6 & 0.18 & 0.27 & 104.7 & 96.0 & 200.7 & 18.5 & 17.4 & 16.3 & 52.2 & 88.54 & 179.3 & 267.84 \\
\hline & $\mathbf{F}$ & & & & & & & & & * & & & & & & & * \\
\hline $\begin{array}{l}\mathrm{Pc} .=\mathrm{P} \\
\mathrm{Ca}= \\
\mathrm{K}=\mathrm{p}\end{array}$ & $\begin{array}{l}\text { tein } \\
\text { Iciun } \\
\text { tassi }\end{array}$ & & & 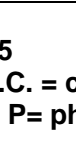 & $0 \mathrm{~s}$ & & & $\begin{array}{l}\text { ent } \\
\text { tage }\end{array}$ & & & & & & & & & \\
\hline
\end{tabular}


Table(11): Effect of potassium fertilization on Protein $\%$, carbohydrate $\%, \mathrm{ca} \%, \mathrm{pH}, \mathrm{P} \%$ and $\mathrm{K} \%$ of three squash varieties and its relation with certain homopterous insects infestation during 2007 season

\begin{tabular}{|c|c|c|c|c|c|c|c|c|c|c|c|c|c|c|c|c|c|}
\hline \multirow{2}{*}{ variety } & \multirow{3}{*}{ Treatments } & \multirow{3}{*}{ P.C } & \multirow{2}{*}{ C.c } & \multirow{3}{*}{$\mathrm{Ca} \%$} & \multirow{3}{*}{ pH } & \multirow{3}{*}{ P\% } & \multirow{3}{*}{$\mathbf{K} \%$} & \multirow{3}{*}{\begin{tabular}{|c|}
$A$. \\
gossypii \\
\end{tabular}} & \multirow{3}{*}{$\begin{array}{c}M . \\
\text { persicae }\end{array}$} & \multirow{3}{*}{ Total } & \multirow{3}{*}{$\begin{array}{c}E . \\
\text { decedens }\end{array}$} & \multirow{3}{*}{\multicolumn{2}{|c|}{\begin{tabular}{|c|c|}
$E$. & $C$. \\
decipiens & chinai \\
\end{tabular}}} & \multirow{3}{*}{ Total } & \multirow{2}{*}{\multicolumn{2}{|c|}{ whitefly }} & \multirow{3}{*}{ Total } \\
\hline & & & & & & & & & & & & & & & & & \\
\hline \multirow{4}{*}{ Holland } & & & \begin{tabular}{|l|}
2.4 \\
\end{tabular} & & & & & & & & & & & & $\begin{array}{l}\text { Adult } \\
59.45\end{array}$ & \begin{tabular}{|l} 
immature \\
108.9
\end{tabular} & \\
\hline & 50 & 0.58 & 3.2 & 0.035 & 6.2 & 0.89 & 0.23 & 112.0 & 1.0 & 9 & 23.6 & 19.7 & 21.8 & .1 & 1.72 & 9 & 47.62 \\
\hline & 100 & 0.69 & 3.6 & 0.04 & 6.5 & 0.09 & 0.25 & 101.63 & 135.27 & 236.90 & 19.3 & 16.6 & 18.4 & \begin{tabular}{|l|l}
54.3 \\
\end{tabular} & 42.54 & 79.6 & 122.14 \\
\hline & 200 & 0.76 & 3.9 & 0.037 & 6.8 & 0.85 & 0.24 & 92.0 & 131.45 & 223.45 & 16.4 & 13.4 & 15.5 & 45.3 & 36.72 & 68.2 & 104.92 \\
\hline \multirow[t]{4}{*}{ Escandarwani } & zero & 0.54 & 2.7 & 0.032 & 5.6 & 0.17 & 0.23 & 154.54 & 179.36 & 333.9 & 34.1 & 27.3 & 34.2 & 95.6 & 77.27 & 132.6 & 209.87 \\
\hline & 50 & 0.64 & 3.5 & 0.034 & 6.4 & 0.18 & 0.26 & 142.18 & 166.90 & 309.08 & 29.8 & 23.3 & 29.3 & 82.4 & 69.45 & 117.4 & 186.85 \\
\hline & 100 & 0.72 & 3.8 & 0.047 & 6.6 & 0.19 & 0.25 & 130.18 & 154.72 & 284.9 & 25.1 & 19.5 & 24.6 & 69.2 & 61.09 & 102.8 & 163.89 \\
\hline & 200 & 0.78 & \begin{tabular}{|l|}
4.0 \\
\end{tabular} & 0.036 & 6.9 & 0.16 & 0.24 & 120.81 & 139.63 & 260.44 & 19.9 & 15.5 & 20.7 & 56.1 & 54.72 & 84.2 & 138.92 \\
\hline \multirow[t]{5}{*}{ Top Kapi } & zero & 0.58 & 2.8 & 0.033 & 5.9 & 0.18 & 0.25 & 191.09 & 191.72 & 382.81 & 36.6 & 33.0 & 42.5 & 112.1 & 85.09 & 157.7 & 242.79 \\
\hline & 50 & 0.66 & 3.6 & 0.044 & 6.5 & 0.10 & 0.23 & 175.54 & 180.81 & 356.35 & 33.4 & 29.0 & 38.0 & 100.4 & 76.45 & 144.1 & 220.55 \\
\hline & 100 & 0.75 & 3.9 & 0.036 & 6.7 & 0.09 & 0.24 & 162.54 & 166.63 & 329.17 & 28.8 & 24.1 & 32.9 & 85.8 & 67.81 & 128.5 & 196.31 \\
\hline & 200 & 0.81 & 4.1 & 0.041 & 7.0 & 0.08 & 0.25 & 144.09 & 149.09 & 293.18 & 25.1 & 19.7 & 28.6 & \begin{tabular}{|l|l|}
73.4 \\
\end{tabular} & 59.90 & 107.5 & \begin{tabular}{|l|}
167.4 \\
\end{tabular} \\
\hline & $\mathrm{F}$ & & & & & & & & & 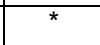 & & & & & & & \\
\hline
\end{tabular}

N.B.: ${ }^{*} \mathrm{~F}$ is significant at $\mathrm{P}>0.05$

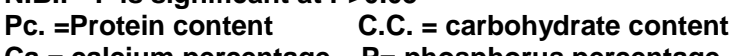

$\mathrm{Ca}=$ calcium percentage $\mathrm{P}=$ phosphorus percentage

$\mathrm{K}=$ potassium percentage 